José João Abrantes

Universidade Nova de Lisboa, Portugal

\title{
THE CRISIS AND THE FUTURE OF THE SOCIAL STATE. REMARKS IN THE LIGHT OF THE PORTUGAL MEMBERSHIP IN THE STRUCTURES OF THE EU ${ }^{1}$
}

\begin{abstract}
The financial crisis that has affected Europe became a multi-dimension phenomenon. It has caused changes not only in the macroeconomic sphere, but also in the political and social sphere as well as in the labour law area.

And so as an example of the great changes in that matter we can see what happened in Portugal, where most of the more recent legislative measures in the area of employment legislation and labour market (as in general in the area of economic policies) assure the compliance with several obligations foreseen in the Memorandum of Understanding, signed in May 2011 between Portugal, the European Commission, the International Monetary Fund and the European Central Bank. Having all that in mind, author intends to analyze the changes in the Portugal's labour law caused by the financial crisis.
\end{abstract}

\section{Key words}

social stare, capitalism, liberalism, neoliberalism, labour law

1 The present text served as the basis for a conference of the author in April $10^{\text {th }} 2013$ in the National Defence University of Warsaw, to whom I express my gratitude for giving me the opportunity of making this conference and also of publishing it in its scientific journal. To discuss the crisis and the future of the Social State is also, according to my view, an act of citizenship, a way of expressing our concern with the actual status of the welfare State. 